


\title{
EFFECT OF DIFFERENT SUPPLEMENT ON DEGRADATION OF DRY MATTER AND FIBER OF UNTREATED AND UREA TREATED RICE STRAW IN THE RUMEN OF SHEEP
}

\author{
D. Yulistiani' ${ }^{1}$ Z.A. Jelan ${ }^{2}$, J.B. Liang ${ }^{3}$ and N. Abdullah ${ }^{4}$ \\ ${ }^{1}$ Research Institute for Animal Production, PO Box 221. Bogor 16002 - Indonesia \\ ${ }^{2}$ Department of Animal Science, Faculty of Agriculture, \\ University Putra Malaysia,Serdang, Selangor 43400 - Malaysia \\ ${ }^{3}$ Institute of Bioscience, University Putra Malaysia, Serdang, Selangor 43400 - Malaysia \\ ${ }^{4}$ Department of Microbiology, Faculty of Biotechnology and Cell Molecular, \\ University Putra Malaysia, Serdang, Selangor 43400 - Malaysia \\ Corresponding E-mail:dwiyulistiani@yahoo.com
}

Received October 01, 2011; Accepted November 29, 2011

\begin{abstract}
ABSTRAK
Penelitian dilakukan dengan tujuan untuk mempelajari degradasi bahan kering (BK) dan serat deterjen netral (SDN) dari jerami padi yang tidak diberi urea (URS) dan yang diberi perlakuan urea (TRS) yang diinkubasi dalam rumen domba dengan pakan yang berbeda. Tiga domba fistula diberi pakan dasar jerami padi yang diberi perlakukan urea dan tiga perlakuan pakan suplemen yang terdiri dari pakan kontrol (T0) murbei dan molasses; murbei, dedak padi dan urea (T1); dan dedak padi dan urea (T2). URS dan TRS dimasukan dalam kantong nylon dan diinkubasi di dalam rumen selama 0, 8, 16, 24, 48 dan 72 jam. Parameter yang diamati adalah degradasi BK, NDF, rumen $\mathrm{pH}$ dan rumen ammonia. Hasil penelitian menunjukkan bahwa degradasi BK dari URS pada pakan T1 nyata lebih rendah dibanding pakan yang lain. Degradasi fraksi tidak terlarut dari BK dan SDN dari URS pada pakan T1 nyata lebih rendah pada pakan T0 dan T2. Degradasi BK dan SDN dari URS tidak dipengaruhi oleh pakan suplemen. Konsentrasi rumen ammonia dari pakan T1 dan T2 lebih tinggi dibanding T0 tetapi konsentrasi ini lebih tinggi dibanding kosnentrasi minimal yang diperlukan untuk sintesa mikroba rumen. Dari hasil penelitian ini dapat disimpulkan bahwa perbedaan pakan suplemen tidak berpengaruh nyata pada degradasi BK dan SDN dari TRS.
\end{abstract}

Kata kunci: degradasi, jerami padi, suplemen, rumen

\begin{abstract}
The study was conducted to investigate the degradation of dry matter (DM) and neutral detergent fiber (NDF) of urea untreated (URS) and urea treated rice straw (TRS) incubated in the rumen of sheep fed different diet. Three fistulated sheep were fed on urea-treated rice straw basal diet with three supplemental treatment diets which consisted of control diet (T0) mulberry and molasses; mulberry, rice bran and urea (T1); and rice bran and urea (T2). Either URS or TRS was placed in nylon bags and incubated in the rumen at $0,8,16,24,48$ and 72 hours. Parameters recorded were degradation of DM and NDF, rumen $\mathrm{pH}$, rumen ammonia. The results showed that DM degradability of URS of the diet T1 was significantly lower than other diets. Similarly the URS degradability of rumen-insoluble fraction (b) of DM and NDF of T1 diet was significantly lower than those of T0 and T2 diet. DM and NDF degradability of URS was not affected by diets. The rumen ammonia concentration of $\mathrm{T} 1$ and $\mathrm{T} 2$ was significantly higher than those $\mathrm{T} 0$, but still higher than critical ammonia concentration required for rumen microbial synthesis. These results suggest that different supplementations have no significant effect on DM and NDF degradability of TRS.
\end{abstract}

Key words: degradability, rice straw, supplements, rumen

\section{INTRODUCTION}

Due to priority land utilization is for crop production, feeding of ruminants in developing countries are likely depend on crop residues and agricultural by-products with relatively poor 
nutritional values. Rice straw which is one of agricultural by-products is an important ruminants feed in rice based farm system, however, its relatively slow rates of fermentation and lack of sufficient nutrients restrict its utilization by rumen microorganisms and consequently by the host animal. Improvement of ruminant productivity fed on quality roughage possibly can be carried out through increasing its digestibility and voluntary intake. Ammoniation method using urea to improve digestibility of fibrous roughages is an accepted technique and adapted by small farmer in developing countries. The use of urea to treat rice straw has great advantage that is easy and safe to use and provide a source of inorganic nitrogen which straw is deficient (Van Soest, 2006). This due to an adequate nitrogen (N) supply to the rumen microbes is very important to obtain maximal rate digestion of plant cell as well as a high microbial protein synthesis. However, when all other necessary factors in the rumen for optimal cellulolysis such as $\mathrm{pH}$, rumen $\mathrm{NH}_{3}$, mineral and vitamin are kept optimal, digestion of low quality fiber still can be improved by supplementation source of easily digestible cellulose or hemicellulose (Silva and Orskov, 1988). Mulberry is potential to be used as supplement in low quality roughage diets due to its high protein content (Sanchez, 2002) and degradability (Saddul et al., 2005; Yulistiani et al., 2008). Beside its high protein content, the degradability of its organic matter was also high (Jelan and Saddul, 2004), hence it can supply fermentable energy in the rumen. Therefore, it can create favorable condition in the rumen for plant cell wall degrading microorganisms.

The high protein content and high degradability of protein and organic matter of mulberry can create a favourable condition in the rumen for plant cell wall degrading microorganisms (Yulistiani et al., 2008). Previous studies have emphasized on mulberry supplementation as a protein supplement (Patra et al., 2002; Anbarasu et al., 2005; Benavides et al., 2002). Limited studies have been conducted in using mulberry as a source of both fermentable energy and protein for ruminant. The experiments were carried out with the objective of comparing the effect of three dietary supplements (mulberry, mulberry and urea-rice bran mixture, and urearice bran mixture) on in situ degradation (nylon bag technique) of NDF and DM of untreated (URS) and urea-treated rice straw (TRS) in the rumen of sheep fed urea-treated rice straw basal diet.

\section{MATERIALS AND METHODS}

\section{Preparation of Urea-treated Rice Straw}

Rice straw was chopped into $5 \mathrm{~cm}$ and stored in plastic bags. Rice straw (94\% DM) weighing $1000 \mathrm{~kg}$ was treated by spraying $5 \%$ urea solution (1L/kg DM straw), thoroughly mixed and filled in the black plastic bag. The air was removed by careful trampling of the bag $(5 \mathrm{~kg}$ treated straw/bag). The sacks were tightly sealed and stored for 3 weeks. After curing period, the treated straw was evenly spreaded on a concrete floor for 1 day to allow the excess of ammonia to evaporate before feeding to the animals.

\section{Mulberry}

Mulberry grown in the experimental plot of the Department of Animal Science, Universiti Putra Malaysia, Serdang, Selangor, Malaysia, was harvested after about 5-7 weeks re-growth. Foliage was air-dried under shed for 3 days, chopped to about $5 \mathrm{~cm}$ length using electric chopper, further dried for 2 days and stored in bags. At this stage the DM content of mulberry was approximately $90 \%$.

\section{Animals and Feeding}

Three Santa Ines crossbred rams with the average body weight of $35.0 \pm 5.0 \mathrm{~kg}$ were used to determine the in situ rumen degradability of URS and TRS. All animals were fitted with a rumen fistula, housed in individual pen and fed twice daily (09:00 and 17:00 h) in equal portions. The sheep were fed with one of the three dietary treatments, the dietary treatments were as follows: 1. T0 (Control): TRS basal diet + mulberry and molasses supplements

2. T1: TRS basal diet $+50 \%$ mulberry replacement with urea-rice bran mixture

3. T2: TRS basal diet + Total mulberry replacement with urea-rice bran mixture

The diets were formulated iso-nitrogenous and iso-energetic (containing a calculated $\mathrm{CP}$ of $11.4 \%$ and $\mathrm{ME}$ of about $8.32 \mathrm{MJ} / \mathrm{kg}$, respectively). The supplements were offered at $1.2 \%$ BW while rice straw offered ad libitum. Water and mineral licks were available at all time. Table 1 shows the ingredients and chemical composition of the three dietary treatments.

The experiments were carried out for three consecutive periods. Three diets were assessed 
Table 1. Ingredients and Chemical Composition of Experimental Diets

\begin{tabular}{lrrr}
\hline \multirow{2}{*}{ Feed Ingredients } & \multicolumn{1}{c}{ Diet } \\
\cline { 2 - 4 } & \multicolumn{1}{c}{ T0 } & T1 \\
\hline Urea-treated rice straw (\%) & 57.1 & 57.1 & 57.1 \\
Mulberry (\%) & 38.1 & 19.1 & 0 \\
Molasses (\%) & 4.8 & 4.8 & 4.8 \\
Urea (\%) & 0 & 0.7 & 1.3 \\
Rice bran (\%) & 0 & 18.3 & 36.8 \\
& & & \\
Calculated chemical composition & & & 8.3 \\
Energy (ME MJ/kg) & 8.4 & 11.5 & 11.4 \\
Protein (\%) & 11.4 & 90.5 & 90.0 \\
DM (\%) & 91.5 & 89.2 & 88.6 \\
OM (\%) & 90.0 & 55.5 & 47.8 \\
NDF (\%) & 59.8 & 40.0 & 36.3 \\
ADF (\%) & 44.0 & & \\
\hline
\end{tabular}

T0: mulberry and molasses supplements; T1: 50\% of mulberry was replaced urea-rice bran mixture; T2: all mulberry was replaced by urea-rice bran mixture; ME: Metabolisable energy; DM: Dry matter; OM: Organic matter; NDF: Neutral detergent fibre; ADF: Acid detergent fibre

simultaneously in different animals for each period. Before samples were incubated in the rumen, the sheep were given two weeks adjustment period to stabilize intake of the diet. During the incubation period, offered feed was reduced to $80 \%$ of the ad libitum intake to ensure that all of feed were consumed.

At the end of incubation period, rumen fluid from each animal was sampled using a stomach tube at $4 \mathrm{~h}$ after morning feeding. Rumen fluid $\mathrm{pH}$ was measured immediately after sampling using a portable $\mathrm{pH}$ meter. One drop of concentrated sulfuric acid was then added (to stop microbial activity) and the fluid was later centrifuged at $3000 \mathrm{~g}$ for $10 \mathrm{~min}$. After centrifugation, $10 \mathrm{ml}$ of each supernatant was kept in air tight container and stored at $-20^{\circ} \mathrm{C}$ pending analyses of $\mathrm{NH}_{3}-\mathrm{N}$.

Sample preparation and rumen in situ degradation

Dried URS and TRS were ground and screened through 2-mm sieve. Approximately 3 $\mathrm{g}$ of ground URS and TRS were weighed and transferred into nylon bag (size $6 \times 12 \mathrm{~cm}$ ) with an average pore size of $45 \mu \mathrm{m}$ (International Feed Resource Unit, Aberdeen, UK). The samples were prepared in duplicate. All nylon bags were dip into the water for 5 minutes to exclude air and then inserted into the rumen of each cannulated sheep in reverse order for $72,48,24,16,8 \mathrm{~h}$, for each URS and TRS. After incubation, all the bags, including the $0 \mathrm{~h}$ bags were removed and immediately rinsed under tap water, subsequently washed in a washing machine (4 cycles of 5 minute followed by spinning) and dried in forcedair oven at $60^{\circ} \mathrm{C}$ for $72 \mathrm{~h}$ to determine $\mathrm{DM}$ disappearance. Duplicate samples were pooled for chemicals analysis.

\section{Chemical analysis}

Residues of URS and TRS were analyzed for DM and NDF, NDF content was determined according to Van Soest et al. (1991). $\mathrm{NH}_{3}-\mathrm{N}$ was determined by steam distillation and titration method.

\section{Degradability calculation}

In situ degradation for DM, NDF and $\mathrm{CP}$ was analyzed using the non-linear model (Orskov and McDonald, 1979). The equation was $\mathrm{p}=\mathrm{a}+$ $\mathrm{b}\left(1-\mathrm{e}^{-\mathrm{ct}}\right)$ where $\mathrm{p}$ is the amount of nutrient degraded (\%) at time t, $a$ is the intercept of the degradation curve at time zero and represent as water soluble fraction (\%), b is the rumeninsoluble, but slowly degradable fraction (\%), $c$ is the rate constant for degradation of the $b$ fraction $(\% / \mathrm{h})$ and $\mathrm{t}$ is the incubation time (h). The extent of degradation is indicated as potential degradability and was estimated as $(a+b)$. The calculation of the equation was carried out using the NEWAY program (Chen, 1996). 


\section{Statistical analysis}

Data on degradation constants from the in situ study was analysed using GLM procedure of Latin Square (SAS 1990 v 6.2). The model included effects of diets, animal and period.

\section{RESULTS AND DISCUSSION}

\section{Results}

Table 2 shows DM degradation characteristics of URS and TRS incubated in the rumen of sheep fed different dietary supplements. DM degradability of URS was not affected by dietary supplements up to $24 \mathrm{~h}$ incubation. However, after 48 and $72 \mathrm{~h}$ incubation, DM degradation of URS incubated in the rumen of sheep on diet $\mathrm{T} 1$ resulted in significantly lower DM degradability than T0, but it was not significantly $(\mathrm{P}>0.05)$ different to $\mathrm{T} 2$. The $\mathrm{DM}$ degradability of rumen-insoluble $(b)$ fraction was significantly lower in T1. On the other hand, DM degradability of TRS and degradation constant was not affected by different supplementations. Effective degradability of DM of URS and TRS was not affected by dietary supplements.

Table 3 shows NDF degradation at each incubation time and degradation characteristics of $\mathrm{NDF}$ of untreated and urea-treated rice straw in the sheep fed different diet treatments. Fiber degradability (NDF) of URS and TRS at each incubation time was not affected $(\mathrm{P}>0.05)$ by different dietary supplementations. Degradation characteristics (water soluble, rate of degradation of $b$ fraction and effective degradability) of NDF of URS or TRS were not affected by diet treatment except for degradation of insoluble fraction $(b)$ of untreated rice straw which was significantly lower in diet $\mathrm{T} 1$ than other diets.

Table 4 shows concentration of rumen ammonia $\left(\mathrm{NH}_{3}-\mathrm{N}\right)$ and rumen $\mathrm{pH}$ of sheep fed different supplements. Rumen ammonia was affected by supplements, sheep fed on diet T0 was significantly lower than diet $\mathrm{T} 1$ and $\mathrm{T} 2$. On the other hand there was no effect of supplements on rumen $\mathrm{pH}$ with the average of rumen $\mathrm{pH}$ was 6.77 .

\section{Discussion}

The negative effect of large amount of supplementation of readily fermentable carbohydrate in decreasing fiber digestibility has been reported by Sinclair et al. (1993) and Kosloski et al. (2007). In the present study, the DM degradability was only affected by diet treatment in URS and at longer incubation time (48 and 72 hours) where T0 had higher than T1

Table 2. DM Degradability (\%) and Degradation Characteristics of Untreated Rice Straw (URS) and Urea-treated Rice Straw (TRS) at Different Incubation Times in the Rumen of Sheep Fed Different Dietary Supplements

\begin{tabular}{|c|c|c|c|c|c|c|c|c|}
\hline & \multicolumn{4}{|c|}{ URS } & \multicolumn{4}{|c|}{ TRS } \\
\hline & T0 & $\mathrm{T} 1$ & $\mathrm{~T} 2$ & SEM & T0 & $\mathrm{T} 1$ & $\mathrm{~T} 2$ & SEM \\
\hline \multicolumn{9}{|c|}{ Incubation time (h) } \\
\hline 8 & 13.9 & 11.7 & 11.8 & 1.94 & 20.4 & 21.9 & 23.7 & 1.46 \\
\hline 16 & 23.7 & 22.5 & 23.0 & 1.39 & 29.0 & 29.5 & 27.4 & 2.63 \\
\hline 24 & 31.8 & 28.9 & 28.6 & 3.22 & 41.0 & 39.9 & 38.0 & 2.89 \\
\hline 48 & $49.8^{\mathrm{a}}$ & $42.5^{\mathrm{b}}$ & $45.7^{\mathrm{ab}}$ & 1.94 & 58.3 & 54.7 & 53.9 & 0.78 \\
\hline 72 & $53.8^{\mathrm{a}}$ & $46.8^{\mathrm{b}}$ & $52.8^{\mathrm{ab}}$ & 1.90 & 63.8 & 61.8 & 60.7 & 0.84 \\
\hline \multicolumn{9}{|c|}{ Degradation constant $(\%)$} \\
\hline$a$ & 9.5 & 7.9 & 10.2 & 1.20 & 3.7 & 7.1 & 12.4 & 3.75 \\
\hline$b$ & $64.1^{\mathrm{a}}$ & $46.5^{\mathrm{b}}$ & $67.3^{\mathrm{a}}$ & 2.50 & 67.3 & 65.9 & 70.0 & 2.74 \\
\hline$c(/ \mathrm{h})$ & 1.8 & 3.0 & 1.4 & 0.47 & 3.3 & 3.1 & 1.9 & 0.20 \\
\hline ED & 21.1 & 24.6 & 25.6 & 1.38 & 32.5 & 31.6 & 31.3 & 0.93 \\
\hline
\end{tabular}

Means with different superscript in the same row is significantly different $(P<0.05)$

T0: mulberry and molasses supplements; T1: 50\% of mulberry was replaced urea-rice bran mixture; T2: all mulberry was replaced by urea-rice bran mixture; S.E.M.: standard error mean; $n$ s, non significant. $a, b, c$ are degradation constant which reflected: $a$, water soluble fraction; $b$, degradation of rumen-insoluble fraction; and c, rate of degradation of b fraction; ED, effective degradability at outflow rate (fraction/hour) of $0.05 / \mathrm{hr}$ 
Table 3. Fiber (NDF) Degradability (\%) and Degradation Characteristics of Untreated Rice Straw (URS) and Urea-treated Rice Straw (TRS) Incubated at Different Incubation Times in the Rumen of Sheep Fed Different Diets

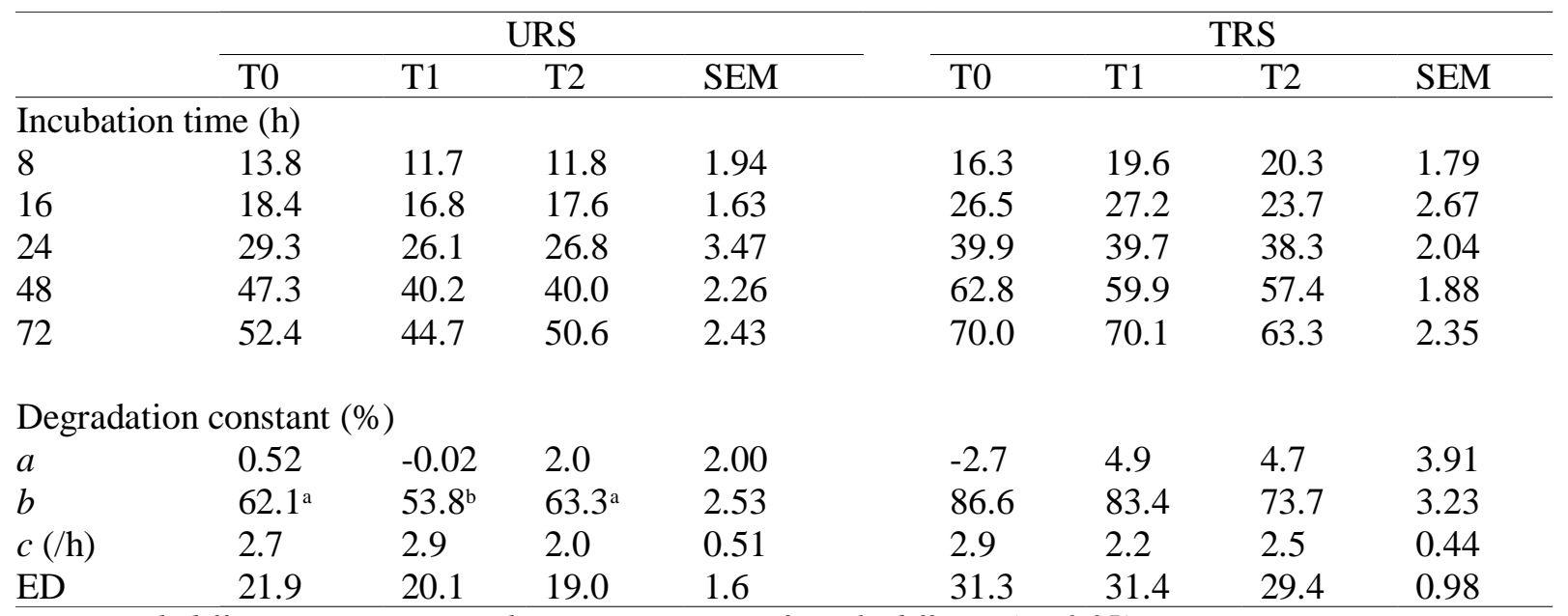

Means with different superscript in the same row is significantly different $(P<0.05)$

T0: mulberry and molasses supplements; T1: 50\% of mulberry was replaced urea-rice bran mixture; T2: all mulberry was replaced by urea-rice bran mixture; S.E.M.: standard error mean; ns, non significant.

$a, b, c$ are degradation constant which reflected: $a$, water soluble fraction; $b$, degradation of rumen-insoluble fraction; and c, rate of degradation of b fraction; ED, effective degradability at outflow rate (fraction/hour) of $0.05 / h r$

Table 4. Rumen Ammonia Concentration and Rumen pH in Sheep Fed Different Supplements

\begin{tabular}{lcccc}
\hline \multirow{2}{*}{ Variables } & \multicolumn{3}{c}{ Supplements } & \multirow{2}{*}{ SEM } \\
\cline { 2 - 4 } & $\mathrm{T} 0$ & $\mathrm{~T} 1$ & $\mathrm{~T} 2$ & 1.48 \\
Rumen $\mathrm{NH}_{3}-\mathrm{N}(\mathrm{mg} / 100 \mathrm{ml})$ & $17.8^{\mathrm{b}}$ & $21.8^{\mathrm{a}}$ & $23.0^{\mathrm{a}}$ & 0.04 \\
Rumen $\mathrm{pH}$ & 6.8 & 6.8 & 6.7 & \\
\hline
\end{tabular}

Means with different superscript in the same row are significantly different

TO : mulberry and molasses supplements

$T 1: 50 \%$ of mulberry was replaced by rice bran and urea

$T 2$ : mulberry was replaced by urea and rice bran

SEM ; standard error mean

but was not significantly different from $\mathrm{T} 2$. However, NDF degradability of either URS or TRS was not affected by supplement. No effect of readily fermentable carbohydrate supplementation in this study was due to the supplementation was only at $1.2 \% \mathrm{BW}$. The initial diet was formulated to contain rice straw of $57.1 \%$ (Table 1) and the rest was supplements that consisted of either mulberry and molasses (T0) or partially mulberry (T1) or totally replaced by urea rice bran mix (T2) in iso-energetic and iso-nitrogenous composition (Table 1). However, in the feeding trial the straw was offered ad libitum but the supplements was offered in a fixed amount at $1.2 \% \mathrm{BW}$. This was carried out to study the effect of different dietary supplementations on the increasing intake of basal diet of urea-treated rice straw (TRS). Since the supplement was given before straw and in limited amount, therefore the supplements was eaten in a few minutes, hence the residue from the feeding was only from urea treated rice straw, which was in the form of tough stem or straw root. Previously Yulistiani et al (2008) reported that supplementation of either mulberry or mulberry replaced partially or totally with urea rice bran mix could stimulate intake of TRS by $20 \%$ higher.

The DM and fiber degradation of URS and TRS were not affected by the type of supplements. This indicates that supplementation of mulberry or mulberry partially replaced by urea-rice bran mixture or totally replaced by urea mixed rice bran resulted in similar effect on fibre 
degradation of URS and TRS by creating efficient rumen ecosystem. This was due to DM and $\mathrm{CP}$ degradation of mulberry was high after 24 hours incubation regardless of the differences diet of the fistulated sheep (Yulistiani et al., 2008). Similarly DM degradation was also high. Rice bran have similar trend to mulberry even its protein degradability was higher than mulberry, which is almost $100 \%$ protein of rice bran was degraded in the rumen after 16 hours incubation. Therefore, when mulberry supplement was replaced by rice bran partly or fully replaced by rice bran and urea could result in similar effect in fiber degradation. In this study, the rumen environment of the sheep fed on three diets was in optimum conditions for fibre degradation. As shown Table 4, the average rumen $\mathrm{pH}$ was 6.77 which is still in optimum for cellulolysis activity of rumen microbe (Duran and Kawashima, 1980) and greater than 5.7 for microbial protein synthesis. Similar report was also reported by Kozloski et al. (2007) on NFC supplementation together with NPN and Mlay et al. (2003) on urea supplementation to low quality of hay. Moreover the rumen $\mathrm{NH}_{3}-\mathrm{N}$ concentration was also in the ideal condition which was 17.8 , 21.8 and $23.0 \mathrm{mg} \mathrm{N} / 100 \mathrm{ml}$ respectively for $\mathrm{T} 0, \mathrm{~T} 1$ and T2 (Table 4). Eventhough T0 has lower rumen $\mathrm{NH}_{3}-\mathrm{N}$ concentration, this concentration still higher than required for rumen microbial growth and optimal fibrous feed degradation. The recommended minimum rumen $\mathrm{NH}_{3}-\mathrm{N}$ concentration for rumen microbial growth is 5 $\mathrm{mg} / 100 \mathrm{ml}$, but higher values $(10-20 \mathrm{mg} / 100 \mathrm{ml})$ had been recommended (Preston and Leng, 1987; Perdok and Leng, 1990) to optimize degradation of fibrous feed. The rumen ammonia concentration was higher in $\mathrm{T} 1$ and $\mathrm{T} 2$ diet which was its protein mulberry was replaced by urea partly (T1) or fully (T2). Previous studies have also reported that $\mathrm{NH}_{3}-\mathrm{N}$ was higher when true protein replaced by urea (casein and soy bean cake, respectively), which caused excess of $\mathrm{NH}_{3}^{-}$ $\mathrm{N}$ concentration in few hours after feeding (Arroquy et al., 2004; Mlay et al., 2003). From the rumen characteristics it was also shown that replacement of protein mulberry with urea did not result in negative effect on fibre degradability similar result was also reported by Mlay et al. (2003) that there was no effect of different sources of fermentable protein (NPN or true protein) on fiber digestibility of hay.

These results suggest that different rumen environments created by different supplementations did not decrease the DM and NDF degradability of URS and TRS, eventhough the sources of fermentable energy and $\mathrm{N}$ were from different ingredients. It seems that the replacement of fermentable carbohydrate of mulberry by starch polysaccharide derived from rice bran did not result in detrimental effect on fibre degradation. This was probably due to low (30\% of total DMI) level of supplementation (Table 2) and did not affect rumen fibrolytic activity. Martin and Michalet-Derau (1995) also reported that barley supplementation at $0-35 \%$ of total diet did not affect the colonization of feed particle by cellulolytic rumen bacteria, hence did not affect fibre digestion. However, when the level of barley supplementation increased up to $60 \%$ of total DMI, hay fibre degradability decreased due to the reduce of the rumen fibrolytic bacteria activity (Martin et al., 2001). This indicates that the three supplements diets formulated in the present study were capable in creating the optimum conditions of rumen fermentation for fibre digestibility, by supplying fermentable energy and protein. Previously, Yulistiani et al. (2008) reported that when urea treated rice straw was offered ad libitum in the diet, these three supplements increased intake of urea-treated rice straw basal diet by $20 \%$. Similar to energy, the $\mathrm{N}$ supplementation can be achieved either from mulberry or urea. Hence, the results from this study offer an alternative source of nitrogen and energy for TRS feeds, either from mulberry or urea plus rice bran without any detrimental effect on fiber degradability of URS and TRS in the rumen.

DM degradability of URS was lower than TRS at all incubation time. Similarly, the rate of DM degradability (c) of $b$ fraction in URS was also lower than TRS. Similarly, NDF degradability of insoluble fraction (b) was also higher in urea treated rice straw (TRS). From DM and NDF degradability it shows that even in ideal condition of rumen environment for fibre degradation which created by diet treatment, but untreated rice straw (URS) still have lower degradation. This results indicates the need for pretreatment of low quality roughages such as rice straw to improve its degradation. In the secondary lignified cell wall such as those found in straw, the nature of cross linking between structural carbohydrate and lignin means more hemicelluloses is bound to lignin, and therefore, the hemicelluloses becomes unavailable for rumen degradation (Chesson, 1988). Alkali 
treatment such as urea treatment disrupt the ester bond between lignin and hemicelluloses, resulting in the hemicelluloses becoming available for digestion (Chesson, 1988). Beside lignin, silica is the limiting factor to rice straw quality. Rice straw is one of plants type which accumulate silica in their tissue through active transport system. Most of silica to be deposited in plant cell and some of the silica is soluble (Van Soest, 2006). Urea treatment disrupt the silicified cuticular barrier in rice straw leaves which result in increasing of NDF degradability of urea treated rice straw (Shen et al., 1998).

The effect of urea treatment on degradation characteristics was significant in increasing rate of degradation constant (a) of DM of treated straw. Urea treatment increased rate of degradation by $34 \%$. NDF degradability was also higher in TRS than in URS at all incubation time as well as the increased of all degradation characteristics, except in rate of degradation (c values). Readily soluble fraction (a) of NDF content increased almost 3 fold in urea treated rice straw. Similar results was also reported by Shen et al. (1998) and Selim et al. (2002) that urea treatment increased content of small soluble molecules of NDF in urea treated rice straw. The higher degradability of NDF in TRS was caused by improving cellulose degradation due to the release of phenolic group from the cell wall matrix (Shen et al., 1998; Van Soest, 2006) beside that urea treatment also improved the extraction of silica from cell wall, therefore increased the availability of cellulose for microbial degradation (Shen et al., 1998). Moreover, Selim et al. (2002) reported that increased of fragility of inside and outside cell wall structure and decreased the content of phenolic and uronic and acetyl groups of cell wall polysaccharides due to ammonia treatment caused the increased accessibility of rumen microorganism to the cell wall as a result bacterial mass and bacterial attachment to the treated straw increased and finally increased straw digestibility.

The increase of degradability of insoluble fraction and the rate of degradation resulting from urea treatment has also been reported by Ibrahim et al. (1989); Yulistiani et al. (1998); Shen et al (1998) and Selim et al. (2002).

\section{CONCLUSION}

Mulberry supplementation in urea-treated rice straw based diet provides fermentable energy and fermentable protein. Rumen degradation of fiber of untreated and urea-treated rice straw was similar in sheep fed urea-treated rice straw basal diet supplemented with mulberry or urea-rice bran mixture. Mulberry or urea with rice bran offers an alternative source of $\mathrm{N}$ and energy in the diet of sheep fed rice straw basal diet. Urea treatment increased degradation of DM and NDF of rice straw.

\section{REFERENCES}

Anbarasu, C., N. Dutta, K. Sharma and M. Rawat. 2004. Response of goats to partial replacement of dietary protein by a leaf meal mixture containing Leucaena leucocephala, Morus alba and Tectona grandis. Small Rum. Res. 51: 47-56.

Arroquy, J.I., R.C. Cochran, T.A. Wickersham, D.A. Llewellyn, E.C. Titgemeyer, T.G. Nagaraja and D.E. Johnson, 2004. Effects of type of supplemental carbohydrate and source of supplemental rumen degradable protein on low quality forage utilization by steers. Anim. Feed Sci. Technol. 115: 247-263.

Benavides, J. 2002. Anex 2. Utilization of mulberry in animal production system. In: Mulberry for Animal Production. (M.D. Sanchez, ed.). Animal Production and Health Paper. No. 147. FAO Rome, Italy. P. 291-327

Chen, X.B. 1996. An Excel Application Program for processing Feed Degradability Data. User Manual, Rowett Research Institute, Buchsburn, Aberdeen, UK.

Chesson, A. 1988. Lignin-polysaccharide complexes of the plant cell wall and their effect on microbial degradation in the rumen. Anim. Feed Sci. Tech. 21: 219-228.

Durand, M. and R. Kawashima. 1980. Influence of minerals in rumen microbial digestion. In. Digestive Physiology and Metabolism In Ruminants, (Y. Ruckebusch and P. Thivend, eds.). Lancaster, UK: MTP Press. P. 375-408.

Jelan, Z.A. and D. Saddul. 2004. Mulberry as feed for ruminant. In Proceedings 2004 International Symposium on Recent Advances in Animal Nutrition. Kuala Lumpur, Malaysia, September 7, 2004. pp. 110-115.

Kozloski, G.V., M.V. Reffatti, L.M. Bonnecarrère Sanchez, L.D. Lima, R.L. Cadorin Jr, C.J. Härter and G. Fiorentini. 2007. Intake and digestion by lamb as fed a low-quality grass hay supplemented or not with urea, casein or cassava meal. Anim. Feed. Sci. Technol. 136: 
191-202.

Martin C. and B.Michalet-Doreau, 1995. Variations in mass and enzyme activity of rumen microorganisms: effect of barley and buffers supplements. J. Sci. Food Agric. 67: 409-415.

Martin, C., L. Millet, G. Fonty and B. MichaletDoreau. 2001. Cereal supplementation modified the fibrolytic activity but not the structure of the cellulolytic bacterial community associated with rumen solid digesta. Reprod. Nutr. Dev. 41: 413-424.

Mlay, P.S., A.E. Pereka, M.R. Weisbjerg, T. Hvelplund and J. Madsen. 2003. Digestion and passage kinetics in fiber in mature dairy heifers maintained on poor quality hay as affected by the source and level of nitrogen supplementation. Anim. Feed Sci. Technol. 109: 19-33.

Ørskov, E.R. and I. McDonald, 1979. The estimation of protein degradability in the rumen from incubation measurements weighted according to the rate passage. J. Agric. Sci. Camb. 92: 499-503.

Patra, A.K., K. Sharma, N. Dutta and A.K. Pattanaik. 2002. Effect of partial replacement of dietary protein by a leaf meal mixture containing Leucaena leucocephala, Morus alba and Azadirachta indica on performance of goats. Asian-Aust. J. Anim. Sci. 15: 17321737.

Perdok, H.B. and R.A. Leng, 1990. Effect of supplementation with protein meal on the growth of cattle given a basal diet of untreated or ammoniated rice straw. AsianAust. J. Agric. Sci. 3: 269-279.

Preston, T.R. and R.A. Leng, 1987. Matching Ruminant Production Systems with Available Resources in The Tropics and Sub-Tropics. Penambul Books, Armidale, New South Wales, Australia.

Saddul, D., Z.A. Jelan, J.B. Liang and R.A. Halim. 2005. Evaluation of mulberry (Morus alba) as potential feed supplement for ruminants: The effect of plant maturity on in situ disappearance and in vitro intestinal digestibility of plant fractions. Asian-Aust. J. Anim. Sci.18 (11): 1569-1574.

Sanchez, M.D. 2002. Annex1. Mulberry, an exceptional forage available almost worldwide. In: Mulberry for Animal Production. (M.D. Sanchez, ed.) Animal Production and Health Paper. No. 147. FAO Rome, Italy. pp. 271-290.

SAS. 1989. SAS/STAT User's Guide (Release 6.12) SAS Inst, Inc. Carry, NC, USA.

Selim. A.S.M., J. Pan, T. Susuki, K. Ueda, Y. Kobayashi and K. Tanaka. 2002. Postprandial changes in particle associated ruminal bacteria in sheep fed ammoniated rice straw. Anim. Feed Sci. Tech. 102: 207-215.

Shen, H.S., F. Sundstol and D.B. Ni. 1998. Studies on untreated and urea-treated rice straw from three cultivation seasons: 2 . Evaluation of straw quality through in vitro gas production and in sacco degradation measurements. Anim. Feed Sci. Tech. 74:193-212.

Silva, T. Ayona and E.R. Orskov. 1988. The effect of five different supplements on the degradation of straw in sheep given untreated barley straw. Anim. Feed Sci. Technol. 19: 289-298.

Sinclair, L.A., P.C. Garnsworthy, J.R. Newbold and P.J. Buttery. 1993. Effect of synchronizing the rate of dietary energy and nitrogen release on rumen fermentation and microbial protein synthesis in sheep. J. Agric. Sci. Camb. 120: 251-263.

Van Soest, P.J. 2006. Rice straw, the role of silica and treatments to improve quality. Review. Anim. Feed Sci. Technol. 130: 137-171

Van Soest. P.J., J.B. Robertson, and B.A. Lewis. 1991. Methods for dietary fiber, neutral detergent fiber and non-starch polysaccharides in relation to animal nutrition. J. Dairy Sci. 74: 3583-3593.

Yulistiani, D., Z.A. Jelan and J.B. Liang. 2008. Degradability of mulberry (Morus alba) and Rice Bran in the rumen of sheep fed different diet. Jurnal Ilmu Ternak dan Veteriner. 13(4): 264-272 